\title{
Sedimentary environment and the controlling factors of organic-rich rocks in the Lucaogou Formation of the Jimusar Sag, Junggar Basin, NW China
}

\author{
Chang-Sheng $\mathrm{Qu}^{1,2} \cdot$ Long-Wei Qiu ${ }^{1,3} \cdot$ Ying-Chang Cao ${ }^{1,3} \cdot$ Yong-Qiang Yang ${ }^{1,3} \cdot$ Kuan-Hong $\mathrm{Yu}^{1,3}$
}

Received: 24 January 2018 / Published online: 8 August 2019

(c) The Author(s) 2019

\begin{abstract}
The Lucaogou Formation in the Jimusar Sag of the eastern Junggar Basin is an important sedimentary stratum accumulating huge amounts of lacustrine tight oil in China, where organic-rich rocks are commonly observed. Focusing on the Lucaogou Formation, a precise analysis of the inorganic and organic petrology and the inorganic geochemistry characteristics was conducted. The paleoclimate and paleoenvironment during sedimentation of the Lucaogou Formation were established, and the key factors that were controlling the accumulation of organic matter during this time were identified. The results of this study suggest that during the sedimentation of the Lucaogou Formation, the paleoclimate periodically changed from a humid environment to an arid environment. As a result, the salinity of the water and the redox environment fluctuated. During the sedimentation period, the lake showed sufficient nutrient supplies and a high primary productivity. The interval studies in the Lucaogou Formation were divided into five sedimentary cycles, where the first, second, and fifth sedimentary cycles consisted of cyclical paleoclimate fluctuations varied from a humid environment to an arid environment and shifted back to a humid environment with levels of salinity from low to high and decreased again. The third and fourth cycles have cyclical fluctuations from a humid to an arid environment and corresponding salinity variation between low and high levels. During the period when organic-rich rocks in the Lucaogou Formation deposited in the Jimusar Sag, the paleoclimate and the water body were suitable for lower aquatic organisms to flourish. As a result, its paleoproductivity was high, especially during the early period of each cycle. A quiet deep water body is likely to form an anoxic environment at the bottom and is also good for accumulation and preservation of organisms. Fine-grained sediments were accumulated at a low deposition rate, with a low dilution of organic matter. Therefore, high paleoproductivity provided a sufficient volume of organisms in the studied area in a quiet deep water body with an anoxic environment and these were the key factors controlling formation of organic-rich rocks.
\end{abstract}

Keywords Organic-rich rocks $\cdot$ Paleoenvironment $\cdot$ Lucaogou Formation $\cdot$ Jimusar Sag $\cdot$ Junggar Basin

\section{Introduction}

Edited by Jie Hao

Long-Wei Qiu

qiulwsd@163.com

1 School of Geosciences, China University of Petroleum, Qingdao 266580, Shandong, China

2 Shandong University of Science and Technology, Qingdao 266590, Shandong, China

3 Key Laboratory of Deep Oil and Gas Geology and Geophysics, (China University of Petroleum), Ministry of Education, Qingdao 266580, Shandong, China
The Junggar Basin is located in the north of the Xinjiang Uygur Autonomous Region of China and is one of the most important petroliferous basins with abundant oil, gas, and tight oil resources (Jia et al. 2012a, b; Zou et al. 2015a, b, 2016a, b). The Lucaogou Formation is the main source rock for the entire Junggar Basin, as well as an important source for tight oil. In recent years, exploration for tight oil in the Lucaogou Formation has been successful for commercial yields, indicating a large potential for prospective yields in the Jimusar Sag (Kuang et al. 2012; Wang et al. 2014). Typical brackish lacustrine tight oil occurs in the Lucaogou Formation in the Jimusar Sag, which differs greatly from that 
occurring in fresh terrestrial lacustrine environments (Jia et al. 2012b). However, understanding of the Lucaogou Formation has been very limited, as has any exploration efforts. While significant studies have been conducted to identify the key lithological features, reservoir properties, source rock, and the hydrocarbon generation potential (Kuang et al. 2013; Wang et al. 2014; Jiang et al. 2015; Shao et al. 2015; Xi et al. 2015; Gao et al. 2016; Zha et al. 2017; Yang et al. 2017), few studies have focused on the paleoenvironment, the paleoproductivity, or the other factors controlling the accumulation of organic matter. In this work, detailed core observations were made, samples were collected from the common lithologies observed in sedimentary cycles present in the formation, the organic-rich rocks were characterized, and the factors controlling the deposition in brackish, lacustrine environments with a high frequency of water level fluctuation were identified. By identifying and reconstructing the paleoclimate and the paleoenvironment characteristics and their evolution over time, this study sought to identify the key factors controlling the accumulation of organic matter, reveal the distribution of high-quality source rock, and demonstrate the feasibility for tight oil exploration in the region.

\section{Geological setting}

The Jimusar Sag is located on the southeast margin of the Junggar Basin and to the west of the Zhangbei folded belt. This sag is a half-graben sag basin dipping to the west with a westward-trending fault and overlapping in the east. To the north of the Jimusar Sag is the Shaqi Uplift, which is separated by the Jimusar Fault. To the west is the Santai rise with the Xidi and Laozhuangwan Faults in between. The southern boundary is the Santai Fault with an updip trending to the east and connected with the Guxi rise (Fang et al. 2007; Xiang et al. 2013; Kuang et al. 2014). The Jimusar Sag has experienced multiple tectonic movements since the Hercynian orogeny, and Carboniferous, Permian, Triassic, Jurassic, Cretaceous, Eogene, Neogene, and Quaternary sediments were deposited, with formations thickening from the east to the west (Kuang et al. 2013). The Permian unit in the Jimusar Sag is composed of the Jingjingzigou, the Lucaogou, and the Wutonggou Formations moving from bottom to top in the strata (Shao et al. 2015). The Lucaogou Formation, widely distributed in the Jimusar Sag, was formed in a semi-deep to deep lacustrine sedimentary environment. As the most important source rock in the Jimusar Sag, the Lucaogou Formation is thickly bedded over a large area (Kuang et al. 2012; Wang et al. 2014). The Lucaogou Formation is the key source bed for the tight oil and is divided into two members. The second member $\left(\mathrm{P}_{2} l_{2}^{2}\right)$ and the first member $\left(\mathrm{P}_{2} l_{1}^{2}\right)$ are called the upper sweet spot and the lower sweet spot, respectively (Kuang et al. 2013) (Fig. 1). The
Lucaogou Formation in the Jimusar Sag was mainly composed of fine-grained sediments with various mineral compositions, including siliciclastic, carbonate, and volcaniclastic rocks (Jiang et al. 2015; Xi et al. 2015; Qiu et al. 2016).

\section{Sampling and methods}

Core samples were collected from the lower sweet spot with a length of $9.36 \mathrm{~m}$ in Well Ji32 of the Lucaogou Formation in order to explore the tight oil in the Jimusar Sag. Most core samples are dark gray-black, and the samples are fresh and not weathered. The location of well Ji32 is shown in Fig. 1. Based on the detailed core observations, 28 samples were collected systematically and used for analysis. To identify variations in the petrology and the organic matter content, conventional and fluorescent thin sections were made for all samples. Concentrations of major element oxides and trace elements of 23 samples were measured on dissolved samples at the Beijing Research Institute of Uranium Geology (China). The major element oxides were measured by an X-ray fluorescence spectrometer (PW2404, Philips, made in the Netherlands), strictly following the test procedure of GB/T 14506.30-2010. Trace element analysis was undertaken using an inductively coupled plasma mass spectrometer (NeXION300D, Perkin Elmer, made in the USA), strictly following the criteria of GB/T 14506.30-2010 during the test procedures. The analytical error is lower than 5\%. Total organic carbon (TOC) contents were measured using a Leco CS-230 apparatus on 27 samples pre-treated with concentrated $\mathrm{HCl}$ in the geochemical laboratory at Yangtze University, strictly following the criteria of GB/T 19145-2003. Rock-Eval pyrolysis parameters of samples were measured in the geochemical laboratory at Yangtze University, according to the criteria of GB/T 186022012. All samples were crushed and ground to $<200$ mesh.

\section{Results and discussion}

\subsection{Lithology and geochemical parameters}

The lithology of the drill core interval from the Lucaogou Formation in Well Ji32 was black to dark gray, and the mineral composition was primarily comprised of carbonate and felsic grains. The carbonate was primarily dolomitic micrite. The felsic grains were mainly clay-sized, and the localized silt-grade particles were rich in layers, which are thin with frequent interbedding. The core was divided into five sedimentary cycles according to their lithology, grain size, and texture. At the base of each sedimentary cycle, a grayishwhite calcite vein occurred among the mixed black micrite dolomite and clay-sized felsic grains. The grain size regularly coarsened as the content of silt-sized felsic grains increased 


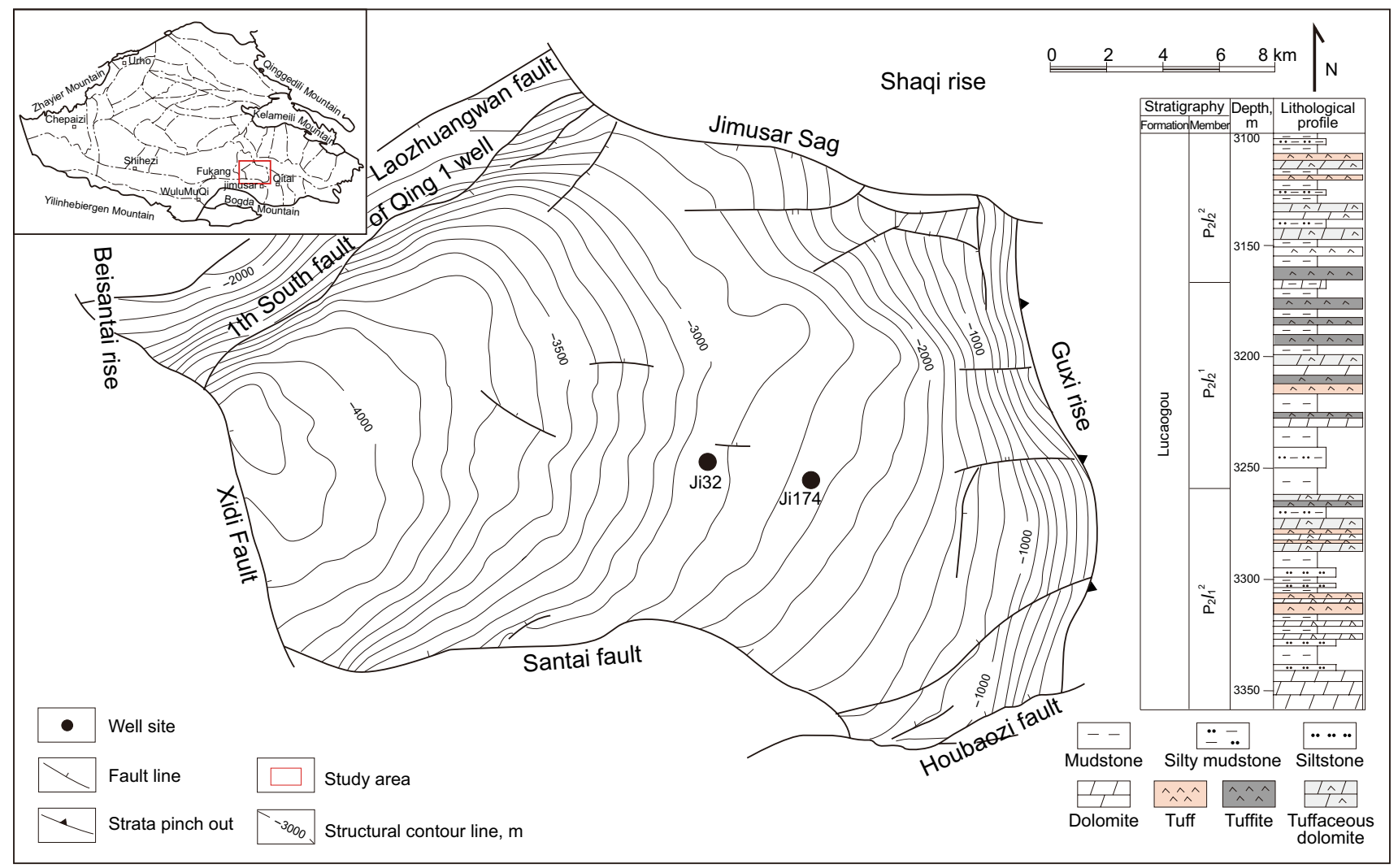

Fig. 1 Location and tectonic map of the Jimusar Sag in the Junggar Basin (modified from Kuang et al. 2012)

upwardly. Sedimentary structures changed from horizontal bedding to laminar or thin-bedded structures, which indicated that frequent fluctuations of the water energy increased from the lower to the upper units (Fig. 2a-f).

The abundance of the organic matter in the samples typically resulted in a high TOC value, varying from $1.73 \%$ to $16.4 \%$ (average being $4.70 \%$ ) (Table 1, Fig. 2g-k, 3). A relationship diagram of HI versus $T_{\max }$ displays that the organic matter was primarily a mixture of type $\mathrm{I}$ and type $\mathrm{II}_{1}$, with minor $\mathrm{II}_{2}$ and III. The thin sections revealed algal laminae in the amorphous or asphaltene phase as the predominant material in the samples. The analysis indicated that the algal laminae may originate from assemblages of planktonic algae and their pyrolysis products. There is occasional inertinite derived from terrestrial plants (Fig. 4).

\subsection{Paleoenvironment analysis}

\subsubsection{Paleoclimate}

Variation in the elemental content in sedimentary rock is directly controlled by its physicochemical properties and is influenced by the paleoclimate and the paleoenvironment. Therefore, the distribution of the chemical elements is a good indicator of the paleoclimate to a certain degree (Hu et al.
2012). $\mathrm{Sr} / \mathrm{Cu}, \mathrm{Rb} / \mathrm{Sr}$ and $\mathrm{Fe}^{3+} / \mathrm{Fe}^{2+}$ ratios are widely used as indicators of changes in the paleoclimate (Wang et al. 1997; Dinescu et al. 2000; Liu et al. 2010a, b; Liang et al. 2017).

$\mathrm{The} \mathrm{Sr} / \mathrm{Cu}$ ratio is very sensitive to paleoclimate changes. It is commonly thought that a $\mathrm{Sr} / \mathrm{Cu}$ ratio greater than 10 indicates an arid climate (Wang et al. 1997; Hu et al. 2012). $\mathrm{The} \mathrm{Sr} / \mathrm{Cu}$ ratios in the studied interval of the Lucaogou Formation in the Jimusar Sag varied from 2.95 to 41.9 with an average of 16.9. This indicates that an arid climate was dominant during this sedimentary period. According to the variations in trends of the $\mathrm{Sr} / \mathrm{Cu}$ versus depth, values of the $\mathrm{Sr} / \mathrm{Cu}$ ratio in the larger fluctuation range suggest that the paleoclimate frequently alternated between arid and humid conditions. Moreover, the $\mathrm{Fe}^{3+} / \mathrm{Fe}^{2+}$ and $\mathrm{Rb} / \mathrm{Sr}$ ratios of all samples varied from 1.05 to 2.32 and 0.04 to 1.14 , respectively. The results based on the $\mathrm{Fe}^{3+} / \mathrm{Fe}^{2+}$ and $\mathrm{Rb} / \mathrm{Sr}$ ratios are most comply with the changing trend shown by the $\mathrm{Sr} / \mathrm{Cu}$ ratio. We compared the element ratios, core and microscopic observation results. The paleoclimate of sedimentary cycles first, second and fifth varied from a humid climate to an arid climate during the early-middle period and that the climate shifted back to a humid environment during the middle-late period of sedimentation, while that of cycle third and fourth changed from a humid climate in the early period to an arid climate in the later period (Fig. 5). 

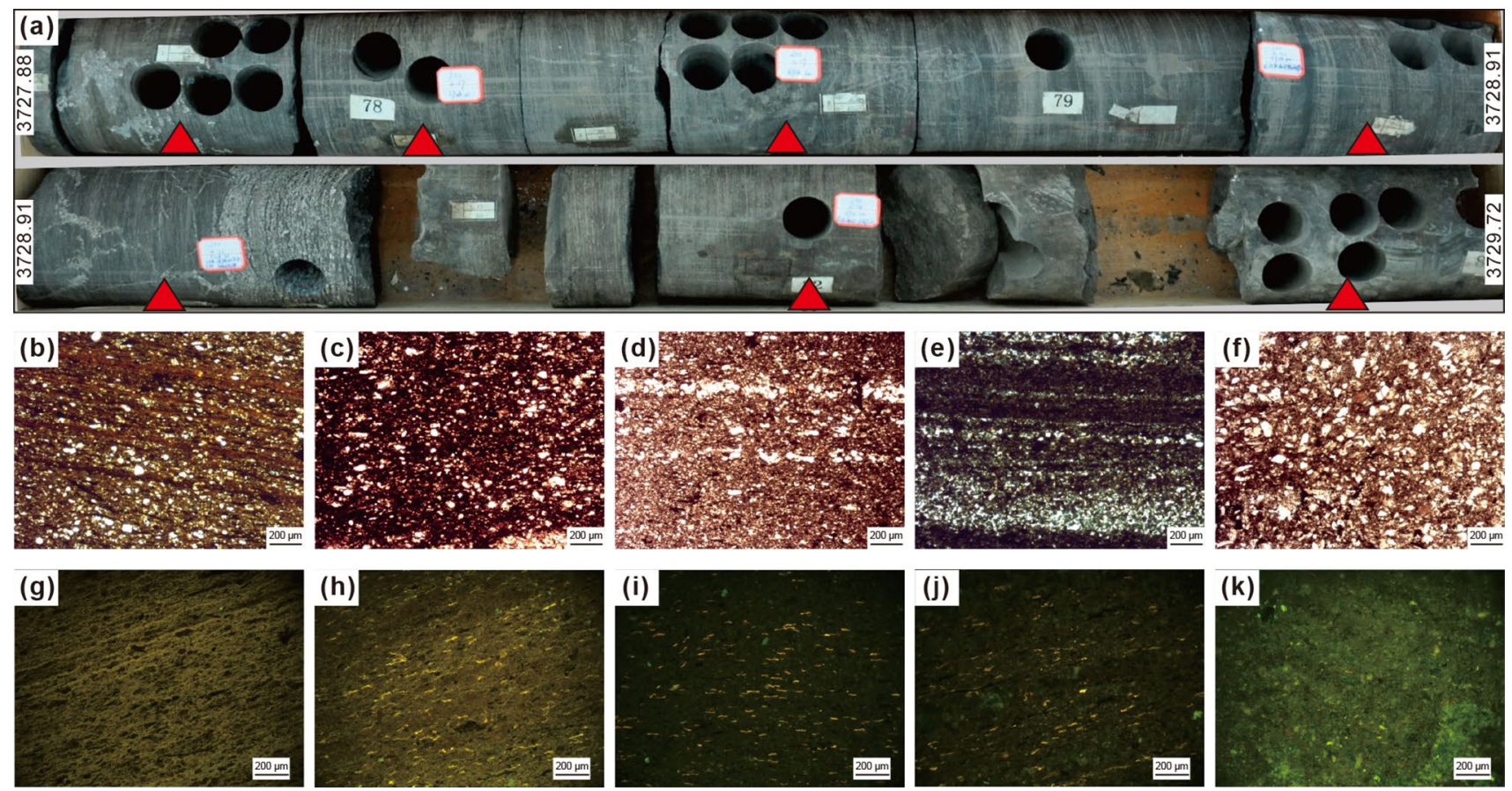

Fig. 2 Lithological and photomicrographs of the samples in Well Ji32. a Core photographs from Well Ji32 (3727.88-3729.72 m), b-f microphotographs of samples under transmitted plane-polarized light, polished sections, $\times 200$, scale bar $=200 \mu \mathrm{m}, \mathbf{g}-\mathbf{k}$ microphotographs of samples under fluorescence blue purple light, polished sections, $\times 200$, scale bar $=200 \mu \mathrm{m}$. The red triangles show the position of core samples

Furthermore, Wu Shaozu and Li Qiang conducted research on the paleoclimate of the Permian in the Junggar Basin (Wu et al. 2002; Li et al. 2002). Their results showed that during sedimentation of the Lucaogou Formation, the basin reflected a greenhouse effect due to the violent volcanic activity from the orogeny associated with plate collisions and the middle Permian was dominated by an arid climate with an intermittent humid climate.

\subsubsection{Paleosalinity}

Based on analysis of paleoclimate, combined with observation of core samples, sedimentary structure, and thin sections under the microscope, sedimentation is summarized as follows. During the early period of each cycle, horizontally laminated beds were the dominant sedimentary structure with a grain size of $50 \mu \mathrm{m}$, indicating that a massive injection of freshwater deepened the water body and decreased salinity (Fig. 2b, c). During middle period of each cycle, crinkly lamina appeared and the grain size increased up to about $100 \mu \mathrm{m}$, indicating that decreasing injection of freshwater and enhanced evaporation resulted in continuous water regression which induced an increase in the lake water salinity (Fig. 2d, e). During the later period of each cycle, due to continuous decrease or slow increase in water level, salinity varied accordingly, and the paleosalinity of lake water was mutually controlled by paleoclimate and the amount of freshwater supply (Fig. 2f). The paleosalinity of the studied interval showed obvious periodical fluctuations, in which the salinity of sedimentary cycles 1, 2 and 5 varied from low to high and decreased again, while that of sedimentary cycles 3 and 4 shifted directly from low to high.

\subsubsection{Redox conditions}

Redox conditions played an important role in the alteration, paragenesis, and precipitation of variable-valence elements. Under oxidizing conditions, such elements occur in a high-valence state and are easily altered. Under reducing conditions, these elements tend to occur in a low-valence state and are easily precipitated. Therefore, trace-metal elements are sensitive to redox conditions and the ratio values are widely used to characterize redox conditions of paleolakes. A previous study showed $\mathrm{V} /(\mathrm{V}+\mathrm{Ni}) \geq 0.6$ indicates an anoxic environment, while $\mathrm{V} /(\mathrm{V}+\mathrm{Ni})<0.46$ indicates oxic environments. Values ranging from 0.46 to 0.6 indicate dysoxic environments (Hatch and Leventhal 1992; Jones and Manning 1994; Adegoke et al. 2014; Brumsack 2006). The $\mathrm{V} /(\mathrm{V}+\mathrm{Ni})$ ratio values found in the studied interval of the Lucaogou Formation ranged between 0.40 and 0.86 with an average of 0.72 . Jones and Manning proposed that the sediments formed in anoxic environments and that $\mathrm{H}_{2} \mathrm{~S}$ appeared in water above the sediments when the $\mathrm{V} / \mathrm{Cr}$ ratio is larger than 4.25. A V/Cr ratio of less than 2.0 implied an 


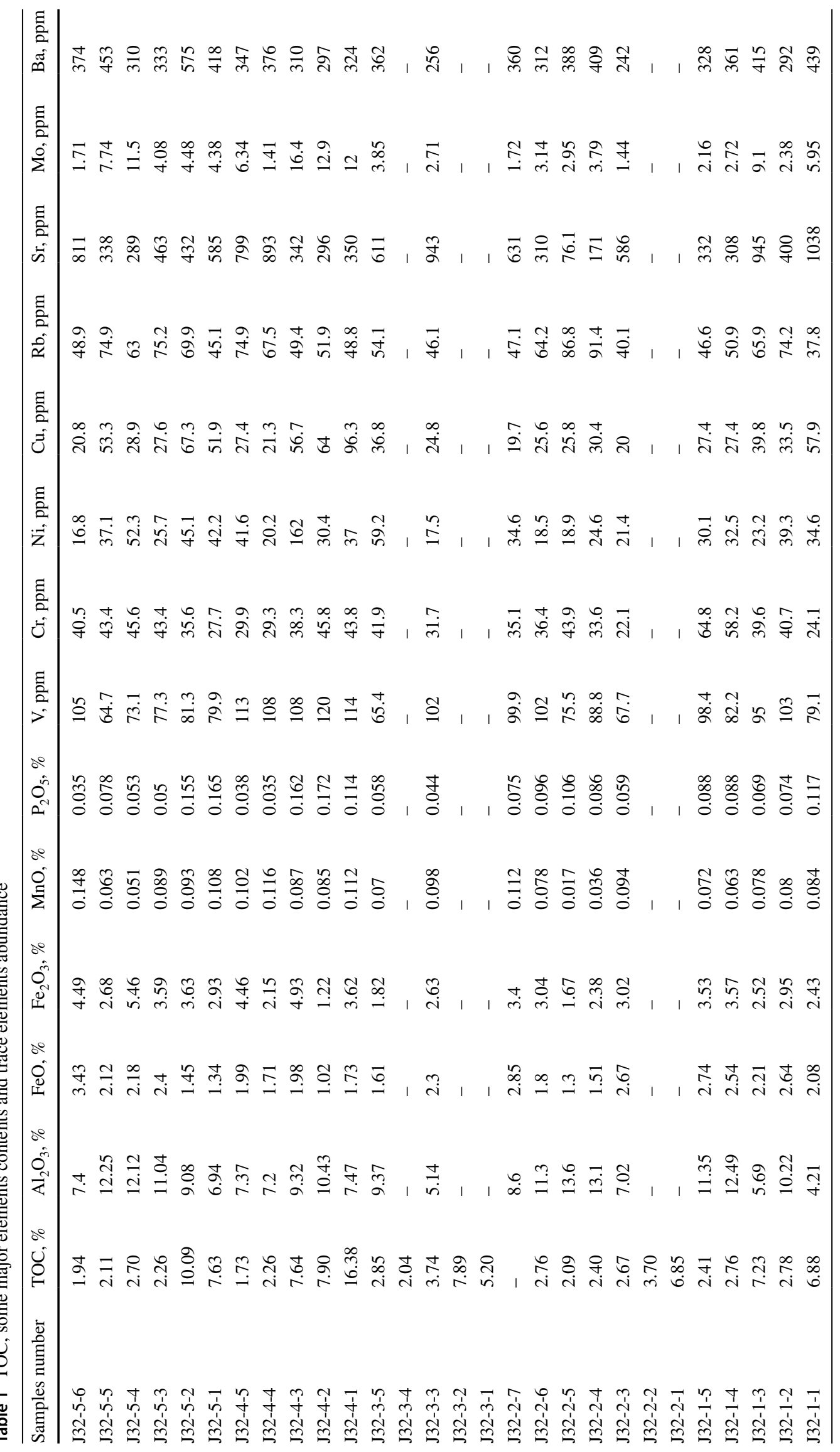




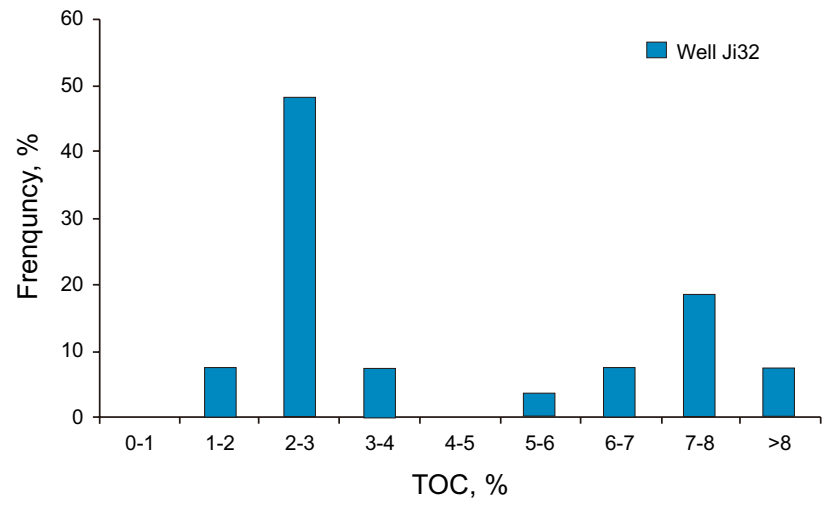

Fig. 3 Frequency diagrams of organic matter abundance in the Lucaogou Formation

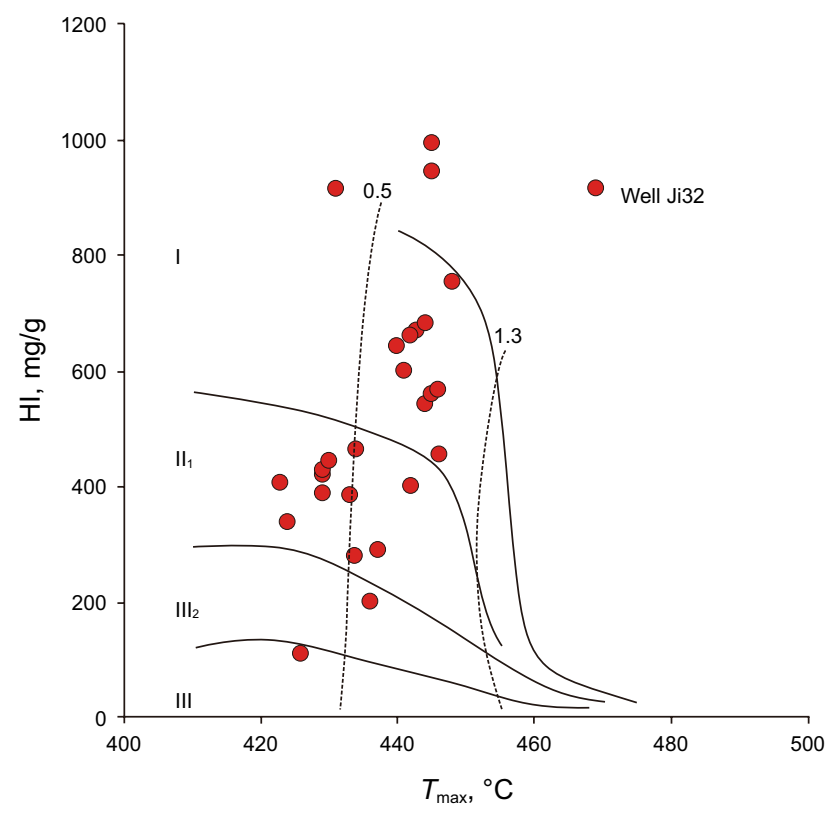

Fig. 4 Organic matter type classification diagram of HI- $T_{\max }$ Lucaogou Formation samples

oxic environment, where a $\mathrm{V} / \mathrm{Cr}$ approximately 1 indicated that the boundary between $\mathrm{O}_{2}$ and $\mathrm{H}_{2} \mathrm{~S}$ occurred within the sediments. The $\mathrm{V} / \mathrm{Cr}$ ratio varied from 2.0 to 4.25 , indicating a transitional environment between sub-oxic to sub-anoxic (Jones and Manning 1994; Wei 2012; Xia et al. 2015). The values of the V/Cr ratio found in the Lucaogou Formation ranged from 1.41 to 3.78 with an average of 2.48. In Fig. 5, the ratios of all of the samples varied violently, indicating frequent alternations between an oxic environment and an anoxic environment. Sedimentary cycles 1, 2 and 5 changed from anoxic environment to oxic environment in the early and middle periods of each cycle and later shifted to an oxic or sub-oxic environment in the middle and late periods of each cycle. Sedimentary cycles 3 and 4 changed from an anoxic environment to oxic environment (Fig. 5).

A high content of organic matter indicated favorable preservation conditions and an anoxic environment. According to the analysis of the core observations, thin sections, and the fluorescent thin sections, the horizontal lamination and algal laminae deposits during the early period of each cycle indicated a quite anoxic environment, which supported the preservation of organic matter. During the middle and late period of each sedimentary cycle, crinkly lamination and bedded structures developed, representing the gradual enhancement of the hydrodynamic forces and little to no amorphous organic matter resulting from degradation effects, implying a transformation to an oxic environment (Fig. 2). Redox environments indicated by the variation of $\mathrm{V} /(\mathrm{V}+\mathrm{Ni})$ and $\mathrm{V} / \mathrm{Cr}$ ratios were consistent with the analysis of sedimentary structures and occurrence of organic matter in samples.

\subsubsection{Paleoproductivity}

Paleoproductivity is a prerequisite for developing concentrations of organic matter. High-quality source rocks are typically related to high paleoproductivity (Chen et al. 2006; Lin et al. 2015). As the main nutrient element which limits the primary productivity of paleolakes, the content of phosphorous $(\mathrm{P})$ positively correlates with productivity. Accumulation of $\mathrm{Cu}$ and $\mathrm{Ni}$ also has a close correlation with the presence of organic matter. $\mathrm{Cu}$ and $\mathrm{Ni}$ are transported into sediments with organic matter and are kept stable after deposition. Therefore, these elements are ideal indicators for the deposited quantity of organic matter (Tribovillard et al. 2006). Precipitation of $\mathrm{Ba}$ and Mo correlates well with the quantity of the organic matter, making them important parameters to evaluate the primary productivity (Tyrrell 1999; Wei 2012; Liu et al. 2010a, b).

The ranges in content of $\mathrm{P}, \mathrm{Cu}, \mathrm{Ni}, \mathrm{Ba}$, and $\mathrm{Mo}$ were $0.035 \%$ to $0.172 \%$ (average $0.088 \%$ ), $20 \mathrm{ppm}$ to $96 \mathrm{ppm}$ (average $39 \mathrm{ppm}$ ), $17 \mathrm{ppm}$ to $162 \mathrm{ppm}$ (average $38 \mathrm{ppm}$ ), $242 \mathrm{ppm}$ to $575 \mathrm{ppm}$ (average $360 \mathrm{ppm}$ ), and $1 \mathrm{ppm}$ to $16 \mathrm{ppm}$ (average $5 \mathrm{ppm}$ ), respectively. As is shown in Fig. 6, the ratios of P/Al, $\mathrm{Mo} / \mathrm{Al}, \mathrm{Ni} / \mathrm{Al}, \mathrm{Cu} / \mathrm{Al}$ and $\mathrm{Ba} / \mathrm{Al}$ varied following a similar trend. Vertically, paleoproductivity was high during the early period of each cycle and apparently decreased during middle or later period of each cycle. Variation of these curves is a reflection of periodical fluctuations of paleoproductivity which was also consistent with variations of TOC. According to observations in the fluorescent thin sections and organic petrology analysis, the organic matter in the Lucaogou Formation is mixtures of type I and type $\mathrm{II}_{1}$. Degraded from lacustrine algae, they were amorphous bodies, occurring as algal laminae, laminated or striped ( $\mathrm{Qu}$ et al. 2017). In addition, aquatic organisms were the most important contributor for source rock in the Lucaogou Formation. In samples with a 


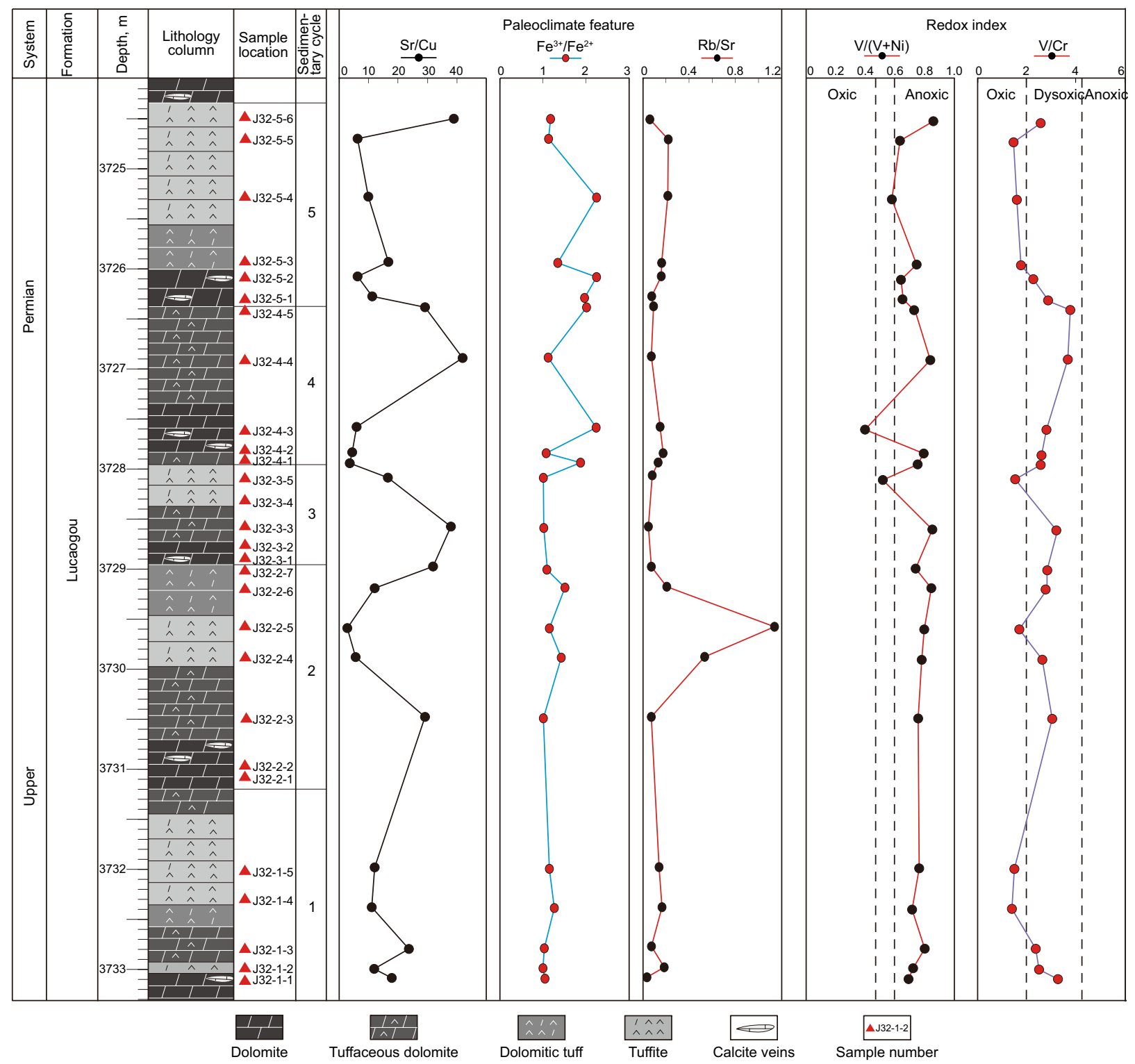

Fig. 5 Relationship diagram of depth versus $\mathrm{Sr} / \mathrm{Cu}, \mathrm{Fe}^{3+} / \mathrm{Fe}^{2+}, \mathrm{Rb} / \mathrm{Sr}, \mathrm{V} /(\mathrm{V}+\mathrm{Ni})$ and $\mathrm{V} / \mathrm{Cr}$

high index of paleoproductivity, content of amorphous bodies was high, and algal laminae with strong yellow fluorescence formed (Fig. 2g, h). On the contrary, in samples with a low index of paleoproductivity, content of amorphous bodies was apparently low and only locally detected (Fig. 2i-k).

\subsection{Primary factors controlling organic-rich rocks}

\subsubsection{Influence of paleoclimate}

The paleoclimate had important effects on the development of the source rock. Variations in temperature and rainfall controlled the paleoproductivity, kerogen type, preservation environment and deposition rate (Lin et al. 2015).
A warm-humid climate favored algal blooms, while a hot-dry climate did the opposite. Under the conditions of a warm-humid climate, massive freshwater injections induced a decrease in salinity, while a hot-arid climate enhanced the evaporation, leading to an increase in salinity. Deepwater and high salinity were advantageous to the formation of a reducing environment ( $\mathrm{Hu}$ et al. 2012; Lin et al. 2015). During sedimentation of the Lucaogou Formation, the paleoclimate changed to hot and dry, and the process is accompanied with ever-increasing paleosalinity of the lake water. That is to say changes in the paleoclimate influenced the paleosalinity during sedimentation. It is speculated that a hot-arid paleoclimate led to an increase in the paleosalinity. On the other hand, a warm-humid paleoclimate resulted in a 


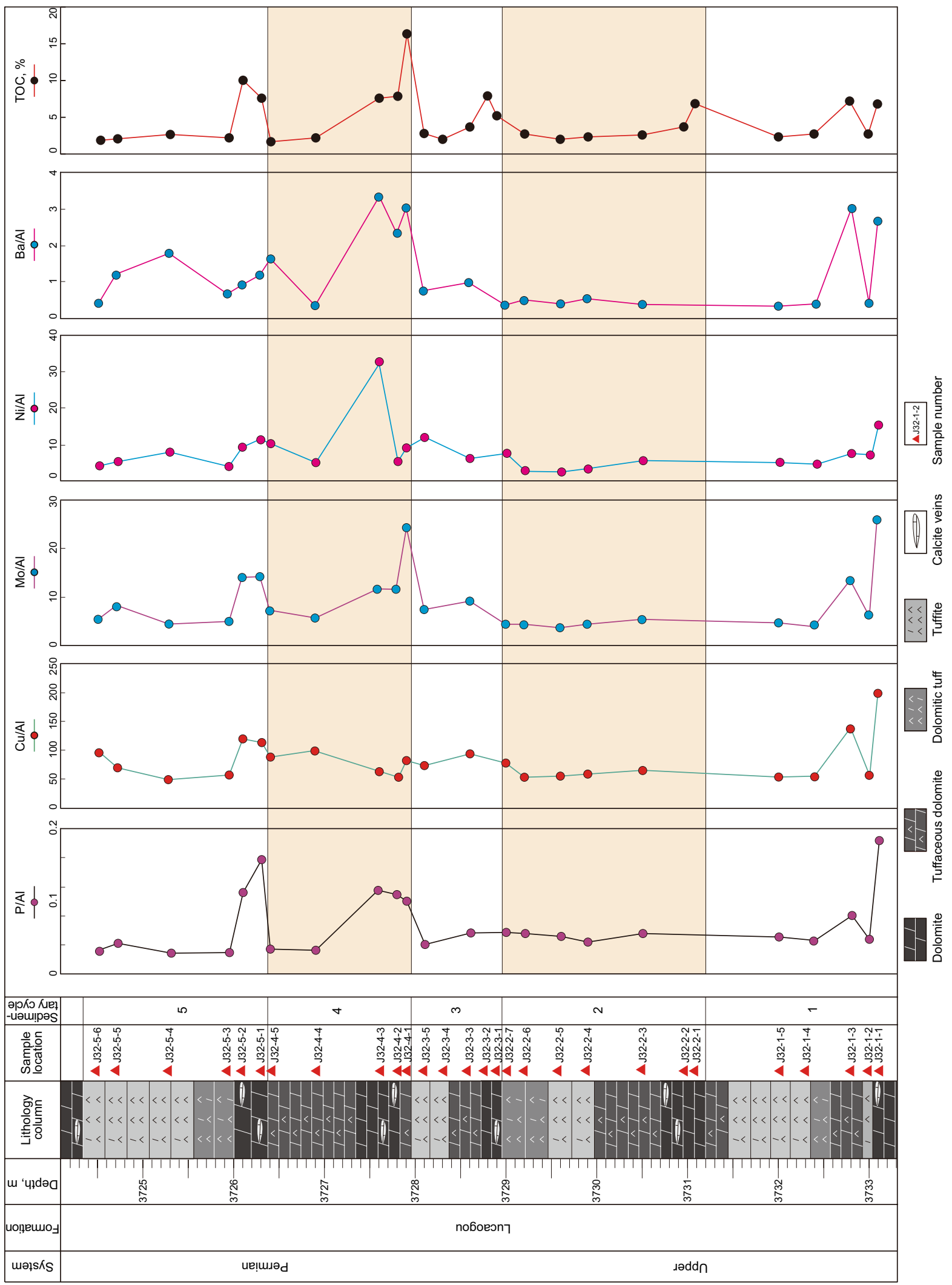

Fig. 6 Relationship diagram of depth versus $\mathrm{P} / \mathrm{Al}, \mathrm{Cu} / \mathrm{Al}, \mathrm{Mo} / \mathrm{Al}, \mathrm{Ni} / \mathrm{Al}, \mathrm{Ba} / \mathrm{Al}$ and TOC 
decreasing paleosalinity. The paleoclimate during the sedimentation of the studied interval of the Lucaogou Formation was dominated by periodic warm-humid and hot-arid climates. The paleosalinity during this time was generally high, as the brackish-saline lake tended to form a reducing environment. A warm-humid paleoclimate was beneficial for organic sources which were mainly aquatic algae and occasionally higher plants. A warm-humid paleoclimate with moderate paleosalinity was favorable for blooms of aquatic algae.

\subsubsection{Influence of paleoproductivity}

Good paleoproductivity was a prerequisite for the formation of source rocks. High-quality source rocks were typically related to high paleoproductivity. Meantime, high paleoproductivity was a guarantee for an accumulation of organic matter and favored the development of reducing conditions for further preservation (Murray et al. 2000; Liu et al. 2013; Lin et al. 2015). As shown in Fig. 7a, b, the $\mathrm{Cu} / \mathrm{Al}$ and $\mathrm{P} /$ Al contents were both directly related to the TOC, with correlation coefficients of 0.84 and 0.69 , respectively, which indicated that strong paleoproductivity provided abundant organic material for organic-rich rocks. The content of nutrient elements, such as $\mathrm{P}$, was positively correlated with the TOC. That is, TOC values increased with the $\mathrm{P}$ content. This relationship indicated that sufficient nutrient elements promoted algal blooms, which enabled a high primary productivity. The high content of the nutrient materials may also be related to volcanic activity within the basin or its peripheral
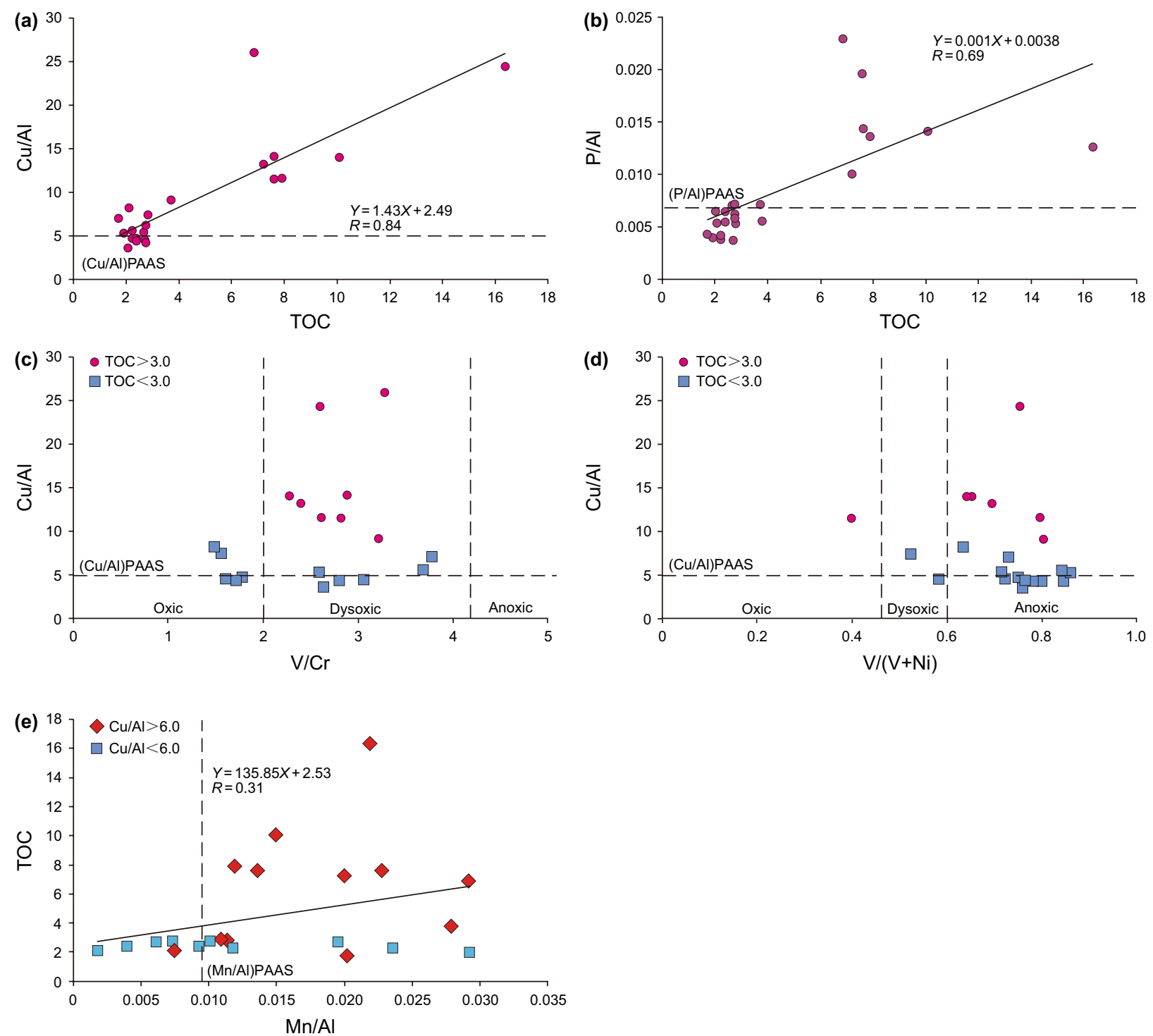

Fig. 7 Discriminant diagram of ancient lake information parameters. (Element/Al)PAAS is the ratio of elements to Al in standard Post-Archean Australian Shale (PAAS) taken from Taylor and McLennan (1985) 


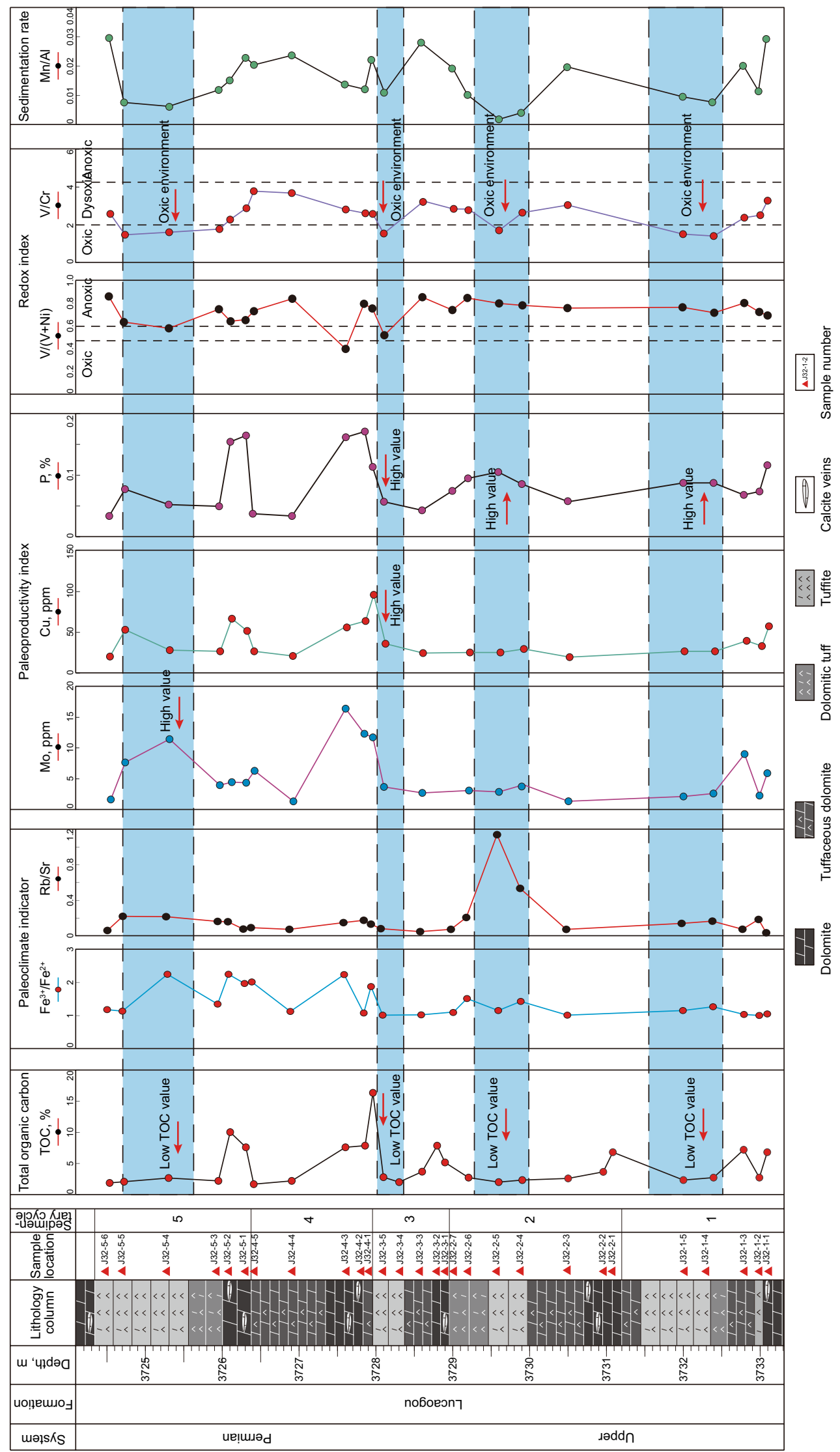

Fig. 8 Comprehensive analysis diagram of the ancient lake information in the organic-rich rocks section 
areas (Jiang et al. 2015; Zhang et al. 2009). Vertically, the change in $\mathrm{P}$ and $\mathrm{Cu}$ content was similar to that of the TOC. According to the statistical analysis, the accumulation of organic-rich rock in the Lucaogou Formation was closely related to the presence of sufficient nutrient materials and high primary productivity (Fig. 8).

\subsubsection{Influence of a redox environment}

Anoxic environments were a critical factor for organism preservation and transformation (Xia et al. 2015). During sedimentation of the Lucaogou Formation, paleoproductivity was generally high with cyclical variation, and the sedimentary environment also varied cyclically from anoxic to oxic. During the early period of each cycle, clay-sized felsic particles were dominant with horizontal laminae and trace elements related to an anoxic environment accumulated, indicating that the water body was free of oxygen (anoxic). As a result, paleoproductivity was high, and the total organic carbon content ranged from $6.88 \%$ to $16.4 \%$. This suggested that an anoxic environment was favorable for preservation of organic matter (Fig. 7c, d). With decreasing water level during the middle period or late period of each cycle, sediments were dominated by silt-sized felsic particles, with thin laminated structures or thin-bedded structures observed. At the same time, the content of trace elements related to the anoxic environment was scarce, and the water body exhibited an oxic or sub-oxic environment. Consequently, paleoproductivity was obviously lower than that during early period of each cycle. Even if there was a chance of high paleoproductivity, it was difficult for organic matter to be preserved due to the oxic environment. Total organic carbon content was low ranging from $1.84 \%$ to $2.78 \%$, which indicated degradation during burial and the adverse effect of the oxic environment on preservation of organic carbon (Fig. 7c, d). Vertically, the oxic-anoxic index varied regularly. The anoxic index was apparently high where the organic matter concentrated. With an increase in oxic degree, the value of TOC decreased accordingly. Taking the late period of the third cycle as an example, contents of paleoproductivity elements such as $\mathrm{P}$ and $\mathrm{Cu}$ increased dramatically. This provided a proof for high paleoproductivity during this period, which coincided well with a low value of the oxic-anoxic index. Lithological composition was mainly bulk silt-sized felsic particles, suggesting a turbulent water body and an oxygen-rich environment. Low values of TOC indicated that under an oxidizing environment, an adequate supply of organic matter was not enough to form organic-rich source rock due to severe degradation (Fig. 8). In summary, during the early period of each cycle in the Lucaogou Formation, a quite anoxic environment with a deep water body was favorable for accumulation of organic matter, and the anoxic environment was a crucial factor controlling the degree of enrichment of organic matter.

\subsubsection{Influence of sedimentation rate}

The sedimentation rate was an important factor influencing the accumulation of organic matter (Schulte et al. 2000; Chen et al. 2006). High sedimentation rates usually diluted the organic matter content. Massive amounts of terrigenous debris were transported into the lake, resulting in a decrease in the organic matter content (Hu et al. 2012). The lithology of the Lucaogou Formation was dominated by clay-sized terrigenous debris with horizontal laminae in the early period of each cycle, while silt-sized terrigenous debris increased in later periods of each cycle. The organic matter was dominated by lacustrine aquatic algae, increasing as a direct result of algal blooms. Sedimentation rates of the terrigenous debris played an important role in the content of organic matter. The Mn content in sediment was an indicator of variations in the deposition rates. Generally, a low $\mathrm{Mn}$ content was a result of a high deposition rate caused by the injection of high-energy river water (Liu et al. 2010a, b). Fine-grained sediments in the Jimusar Sag were formed at very low deposition rate. As shown in Fig. 7e, the ratios of $\mathrm{Mn} / \mathrm{Al}$ were poorly correlated with TOC with a coefficient of 0.3 , indicating the deposition rate of terrigenous detritus had a low influence on organic matter abundance. With the same low deposition rate, differences in TOC were mainly controlled by paleoproductivity and the later preservation environment.

\section{Conclusions}

The paleoclimate during the sedimentation period of the Lucaogou Formation in the Jimusar Sag was dominated by frequent variations between a humid and an arid climate. Influenced by tectonic movement and injections of surface freshwater, the lake level fluctuated cyclically. During the early period of each cycle, the paleoclimate was humid with a massive water injection, resulting in a rapid increase in water depth and the corresponding decrease in salinity. The transformation of the paleoclimate to an arid environment led to increased rates of evaporation, which decreased the water depth and increased salinity.

The lake water contained sufficient nutrients associated with high paleoproductivity. The organic fractions were dominated by lacustrine aquatic algae with a small amount of terrigenous debris. High deposition rates of the terrigenous debris accelerated the dilution of the lacustrine organic substances and dramatically reduced their abundance. The lithology of the Lucaogou Formation is primarily micritic 
dolomite and clay-sized or silt-sized felsic particles. To a certain degree, the high deposition rate of the terrigenous debris reduced the accumulation of organic substances. During the early period of each cycle, the water body was in anoxic conditions, as reflected by deepwater sediments, which facilitated the deposition and preservation of the organic substances. With a decrease in water depth, the turbulent waters transformed the lake into an oxidation environment, leading to the degradation of organic matter and a decrease of TOC. Therefore, under the condition that the high paleoproductivity provided sufficient source organisms for the studied area, a quiet deep water body with an anoxic environment was the key factor controlling the formation of organic-rich rocks.

Acknowledgements This study was supported by the National Science and Technology Major Program of China (Grant No. 2017ZX05009002); the National Basic Research Program of China (Grant No. 2014CB239002); the Natural Science Foundation of Shandong Province, China (Grant No. ZR2014DQ016), and the Natural Science Foundation Joint Special of Shandong Province, China (Grant No. ZR2016DL05).

Open Access This article is distributed under the terms of the Creative Commons Attribution 4.0 International License (http://creativeco mmons.org/licenses/by/4.0/), which permits unrestricted use, distribution, and reproduction in any medium, provided you give appropriate credit to the original author(s) and the source, provide a link to the Creative Commons license, and indicate if changes were made.

\section{References}

Adegoke AK, Abdullah WH, Hakimi MH, et al. Geochemical characterisation of Fika Formation in the Chad (Bornu) Basin, northeastern Nigeria: implications for depositional environment and tectonic setting. Appl Geochem. 2014;43:1-12. https://doi. org/10.1016/j.apgeochem.2014.01.008.

Brumsack HJ. The trace metal content of recent organic carbon-rich sediments: implications for Cretaceous black shale formation. Palaeogeogr Palaeoclimatol Palaeoecol. 2006;232(2):344-61. https ://doi.org/10.1016/j.palaeo.2005.05.011.

Chen JF, Zhang SC, Sun SL, et al. Main factors influencing marine carbonate source rock formation. Acta Geol Sin. 2006;80(3):46772. https://doi.org/10.3321/j.issn:0001-5717.2006.03.021 (in Chinese).

Dinescu LC, Duliu OG, Andries EI. INAA study of the vertical distribution of some major and trace elements in lacustrine sediments of the Danube delta. J Radioanal Nucl Chem. 2000;244(1):14752. https://doi.org/10.1023/A:1006732719230.

Fang SH, Song Y, Xu HM, et al. Relationship between tectonic evolution and petroleum system formation-taking the Jimsar sag of eastern Junggar basin as an example. Pet Geol Exp. 2007;29(2):149-153, 161. https://doi.org/10.3969/j.issn.10016112.2007.02.008 (in Chinese).

Gao G, Zhang WW, Xiang BL, et al. Geochemistry characteristics and hydrocarbon-generating potential of lacustrine source rock in Lucaogou Formation of the Jimusar Sag, Junggar Basin. J Pet Sci Eng. 2016;145:168-82. https://doi.org/10.1016/j.petro 1.2016.03.023.
Hatch JR, Leventhal JS. Relationship between inferred redox potential of the depositional environment and geochemistry of the Upper Pennsylvanian (Missourian) Stark shale member of the Dennis Limestone, Wabaunsee County, Kansas, U. S. A. Chem Geol. 1992;99(1-3):65-82. https://doi.org/10.1016/00092541(92)90031-Y.

$\mathrm{Hu}$ XF, Liu ZJ, Liu R, et al. Clay mineral and inorganic geochemical characteristics of Eocene Huadian Formation in Huadian basin and their paleoenvironment implications. J China Coal Soc. 2012;37(3):416-23. https://doi.org/10.1007/s11783-011$0280-\mathrm{Z}$ (in Chinese).

Jia CZ, Zheng M, Zhang YF. Unconventional hydrocarbon resources in China and the prospect of exploration and development. Pet Explor Dev. 2012a;39(2):129-36. https://doi.org/10.1016/s1876 -3804(12)60026-3 (in Chinese).

Jia CZ, Zou CN, Li JZ, et al. Assessment criteria, main types, basic features and resource prospects of the tight oil in China. Acta Pet Sin. 2012b;33(3):343-50. https://doi.org/10.1016/00319384(73)90235-7 (in Chinese).

Jiang YQ, Liu YQ, Yang Z, et al. Characteristics and origin of tufftype tight oil in Jimusar Depression, Junggar Basin, NW China. Pet Explor Devel. 2015;42(6):741-9. https://doi.org/10.1016/ S1876-3804(15)30077-X (in Chinese).

Jones B, Manning DAC. Comparison of geochemical indices used for the interpretation of palaeoredox conditions in ancient mudstones. Chem Geol. 1994;111(1/4):111-29. https://doi. org/10.1016/0009-2541(94)90085-X.

Kuang LC, Gao G, Xiang BL, et al. Lowest limit of organic carbon content in effective source rocks from Lucaogou Formation in Jimusar Sag. Pet Geol Exp. 2014;36(2):224-9. https://doi. org/10.11781/sysydz201402224 (in Chinese).

Kuang LC, Hu WX, Wang XL, et al. Research of the tight oil reservoir in the Lucaogou Formation in Jimusar Sag: analysis of lithology and porosity characteristics. Geol J China Univ. 2013;19(3):529-35. https://doi.org/10.3969/j.issn10067493.2013.03.015 (in Chinese).

Kuang LC, Tang Y, Lei DW, et al. Formation conditions and exploration potential of tight oil in the Permian saline lacustrine dolomitic rock, Junggar Basin, NW China. Pet Explor Dev. 2012;39(6):657-67. https://doi.org/10.1016/s1876 -3804(12)60095-0 (in Chinese).

Li Q, Wu SZ, Qu X, et al. Key climatic events during CarboniferousTriassic in Junggar. Xinjiang Geol. 2002;20(3):192-5. https://doi. org/10.3969/j.issn.1000-8845.2002.03.003 (in Chinese).

Liang C, Jiang ZX, Cao YC, et al. Sedimentary Characteristics and Paleoenvironment of Shale in the Wufeng-Longmaxi Formation, North Guizhou Province, and Its Shale Gas Potential. J Earth Sci. 2017;28(6):1020-31. https://doi.org/10.1007/s12583-016-0932-x.

Lin JF, Hao F, Hu HY, et al. Depositional environment and controlling factors of source rock in the Shahejie Formation of Langgu sag. Acta Pet Sin. 2015;36(2):163-73. https://doi.org/10.7623/syxb2 01502004 (in Chinese).

Liu A, Li XB, Wang CS, et al. Analysis of geochemical feature and sediment environment for hydrocarbon source rocks of Cambrian in West Hunan-Hubei area. Acta Sedimentol Sin. 2013;31(6):112232. https://doi.org/10.14027/j.cnki.cjxb.2013.06.014 (in Chinese).

Liu R, Liu ZJ, Meng QT, et al. Paleolake evolution of Eocene in Fushun basin. Acta Sedimentol Sin. 2010a;28(4):688-95. https://doi. org/10.14027/j.cnki.cjxb.2010.04.013 (in Chinese).

Liu ZJ, Meng QT, Liu R, et al. Paleolimnology study: taking Huadian fault basin as an example. Acta Sedimentol Sin. 2010b;28(5):91725. https://doi.org/10.14027/j.cnki.cjxb.2010.05.009 (in Chinese).

Murray RW, Knowlton C, Leinen M, et al. Export production and carbonate dissolution in the central equatorial Pacific ocean over the past 1 Myr. Paleoceanography. 2000;15(6):570-92. https://doi. org/10.1029/1999pa000457. 
Qiu Z, Shi ZS, Dong DZ, et al. Geological characteristics of source rock and reservoir of tight oil and its accumulation mechanism: a case study of Permian Lucaogou Formation in Jimusar sag, Junggar basin. Pet Explor Dev. 2016;43(6):928-39. https://doi. org/10.1016/S1876-3804(16)30118-5 (in Chinese).

Qu CS, Qiu LW, Yang YQ, et al. Carbon and oxygen isotope compositions of carbonatic rock from Permian Lucaogou Formation in the Jimsar sag, NW China and their paleolimnological significance. Acta Geol Sin. 2017;91(3):605-16. https://doi.org/10.3969/j. issn.0001-5717.2017.03.008 (in Chinese).

Schulte S, Mangelsdorf K, Rullkotter J. Organic matter preservation on the Pakistan continental margin as revealed by biomarker geochemistry. Org Geochem. 2000;31:1005-22. https://doi. org/10.1016/S0146-6380(00)00108-X.

Shao Y, Yang YQ, Wan M, et al. Sedimentary characteristic and facies evolution of Permian Lucaogou Formation in Jimsar Sag, Junggar Basin. Xinjiang Pet Geol. 2015;36(6):635-41. https://doi. org/10.7657/XJPG20150602 (in Chinese).

Taylor SR, McLennan SM. The continental crust: its composition and evolution. Oxford: Blackwell; 1985.

Tribovillard N, Algeo TJ, Lyons T, et al. Trace metals as paleoredox and paleoproductivity proxies: an update. Chem Geol. 2006;232(12):12-32. https://doi.org/10.1016/j.chemgeo.2006.02.012.

Tyrrell T. The relative influences of nitrogen and phosphorus on oceanic primary production. Nature. 1999;400(6744):525-31. https ://doi.org/10.1038/22941.

Wang SJ, Huang XZ, Tuo JC, et al. Evolutional characteristics and their paleoclimate significance of trace elements in the Hetaoyuan formation, Biyang depression. Acta Sedimentol Sin. 1997;15(1):6570. https://doi.org/10.14027/j.cnki.cjxb.1997.01.012 (in Chinese).

Wang CY, Kuang LC, Gao G, et al. Difference in hydrocarbon generation potential of the shaly source rocks in Jimusar Sag, Permian Lucaogou Formation. Acta Sedimentol Sin. 2014;32(2):385-90. https://doi.org/10.14027/j.cnki.cjxb.2014.02.023 (in Chinese).

Wei HY. Productivity and redox proxies of palaeo-oceans: an overview of elementary geochemistry. Sediment Geol Tethyan Geol. 2012;32(2):76-88. https://doi.org/10.1007/s11783-011-0280-z (in Chinese).

Wu SZ, Qu X, Li Q. Paleoclimatic conditions of Loucaogou and Huangshanjie Formation in Junggar. Xinjiang Geol. 2002;20(3):183-6. https://doi.org/10.1023/A:1014761814254 (in Chinese).
Xi KL, Cao YC, Zhu RK, et al. Rock types and characteristics of tight oil reservoir in Permian Lucaogou Formation, Jimsar sag. Acta Pet Sin. 2015;36(12):1495-507. https://doi.org/10.7623/syxb2 01512004 (in Chinese).

Xia W, Yu BS, Sun MD. Depositional setting and enrichment mechanism of organic matter of the black shales of Niutitang Formation at the bottom of lower Cambrian, in well Yuke1, southeast Chongqing. J Mineral Petrol. 2015;35(2):70-80. https://doi.org/10.19719 /j.cnki.1001-6872.2015.02.009 (in Chinese).

Xiang BL, Liao JD, Zhou N, et al. Organic geochemical features of Permian source rock from Lucaogou Formation in Ji 174 Well of Jimsar depression. Sci Technol Eng. 2013;13(32):9636-40. https ://doi.org/10.3969/j.issn.1671-1815.2013.32.029 (in Chinese).

Yang YQ, Qiu LW, Cao YC, et al. Reservoir quality and diagenesis of the Permian Lucaogou Formation tight carbonates in Jimsar Sag, Junggar Basin, West China. J Earth Sci. 2017;28(6):1032-46. https://doi.org/10.1007/s12583-016-0931-6.

Zha M, Su Y, Gao CH, et al. Tight reservoir space characteristics and controlling factors: an example from Permian Lucaogou Formation in Jimsar sag, Junggar basin, northwest China. J China Univ Min Technol. 2017;46(1):85-95. https://doi.org/10.13247/j.cnki. jcumt.000553 (in Chinese).

Zhang WZ, Yang H, Peng PA, et al. The influence of Late Triassic volcanism on the development of Chang 7 high grade hydrocarbon source rock in Ordos Basin. Geochimica. 2009;38(6):573-82. https://doi.org/10.1016/S1874-8651(10)60080-4 (in Chinese).

Zou CN, Dong DZ, Wang YM, et al. Shale gas in China: characteristics, challenges and prospects (I). Pet Explor Dev. 2015a;42(6):689701. https://doi.org/10.11698/PED.2015.06.01 (in Chinese).

Zou CN, Zhu RK, Bai B, et al. Significance, geologic characteristics, resource potential and future challenges of tight oil and shale oil. Bull Mineral Petrol Geochem. 2015b;34(1):3-17. https://doi. org/10.3969/j.issn.1007-2802.2015.01.001 (in Chinese).

Zou CN, Dong DZ, Wang YM, et al. Shale gas in China: characteristics, challenges and prospects (II). Pet Explor Dev. 2016a;43(2):16678. https://doi.org/10.11698/PED.2016.02.02 (in Chinese).

Zou CN, Yang Z, Pan SQ, et al. Shale gas formation and occurrence in China: an overview of the current status and future potential. Acta Geol Sin (English edition). 2016b;90(4):1249-83. https:// doi.org/10.1111/1755-6724.12769. 